\title{
TESTING THEORIES OF THE DETERMINANTS OF AN INDIVIDUAL FOREIGN POLICY PREFERENCES IN GEORGIA
}

\author{
Angguntari C. Sari ${ }^{1}$ \\ School of Political and Global Studies \\ Arizona State University \\ asari1@asu.edu
}

\begin{abstract}
Public opinion has an impact on statese foreign policy. In the case of Georgia, the pro-Russian or proUnited States attitude among the people is determined by several factors. The strategic value of Georgia for these two most powerful states in the world makes their study of the mass opinion "es preferences toward major power an interesting and a valuable one. In this article, I test two sets of factors that shape the individual preferences toward major powers and employ logistic regression model to explain the relationship between four independent variables with the dependent variable. I argue that religiosity, the role of government, and economic satisfaction are still the best predictors of the pro-Russian policy.
\end{abstract}

Keywords: georgia; public opinion; russia; united states; logistic regression.

\begin{abstract}
Abstrak
Kebijakan luar negeri suatu negara dipengaruhi oleh pendapat para masyarakatnya. Pertanyaannya adalah apa yang mempengaruhi pandangan masyarakat mengenai kebijakan yang selayaknya diambil oleh pemerintah? Artikel ini meneliti faktor-faktor yang dapat mempengaruhi pandangan masyarakat di Georgia mengenai rekan ideal bagi negara mereka. Georgia sendiri merupakan negara yang memiliki nilai strategis bagi negara besar seperti Rusia dan Amerika. Oleh karenanya, kajian mengenai determinan opini publik mengenai siapa diantara kedua negara besar tersebut yang layak menjadi mitra Georgia penting untuk dilakukan. Melalui metode kuantitatif, khususnya pendekatan regresi logistik, artikel ini berusaha melanjutkan penelitian yang terdahulu. Penelitian sebelumnya melihat korelasi antara faktor agama, peran pemerintah, dan kepuasan ekonomi dengan pilihan masyarakat terhadap mitra kerjasama luar negeri Georgia. Satu hal yang luput dari penelitian sebelumnya adalah peran nilai politik. Berdasar analisa melalui model regresi logistik, faktor agama, peran pemerintah, dan kepuasan ekonomi masih menjadi faktor penentu utama pilihan masyarakat Georgia mengenai siapa diantara Amerika dan Rusia yang dianggap ideal menjadi mitra hubungan bilateral negara mereka.
\end{abstract}

Kata kunci: georgia; opini publik; rusia; amerika; regresi logistik.

\section{Introduction}

What explains the variation of foreign policy preferences at the individual level? This is one of the most central, yet understudied topics in the field of Foreign Policy Analysis.

\footnotetext{
${ }^{1}$ The author thanks, Alan James Simmons, Dr. David S. Siroky, Hao Wang, and students at the Polimetrics seminar, Arizona State University, for helpful comments at various stages of this project. I, alone, take responsibility for the content.
}

There are several reasons why studying this topic matters. First, understanding the role of public opinion is important because it can create a constraint, support, or shape foreign policy. ${ }^{2}$

The public opinion is often latent on foreign policy issues. ${ }^{3}$ This is consistent with

\footnotetext{
${ }^{2}$ Steve Chan, and William Safran. "Public Opinion as a Constraint against War: Democracies"e Responses to Operation Iraqi Freedom." Foreign Policy Analysis Vol.2 No. 2(2006):137-156; Matthew A. Baum, and Phillip B.K. Potter. "The

Relationship Between Mass Media, Public Opinion And Foreign Policy: Toward A Theoretical Synthesis." Annual Review of Political Science 11 2008:43-45.

${ }^{3}$ Philip J. Powlick, and Andrew Z. Katz. "Defining the American Public Opinion/Foreign Policy
} 
the conventional wisdom that says the public are often disengaged, and indifferent to international affairs. By latent opinion, it means ingrained sets of values, criteria for judgment, attitudes, and preferences come into play when relevant action, event, or proposal arises.

Latent opinion has the potential to constraint foreign policy officials. Philip J. Powlick and Andrew Z. Katz argue that decision makers must anticipate the future impact of current policies because it has the potential to become activated through major media coverage that is compatible with public frames of reference. ${ }^{4}$ This major media coverage is usually facilitated by elite debate among highly credible expert commentators and government officials. Powlick and Katz contend that decision makers do not always have to worry about what the citizens say all the time because the public engages in foreign affairs only under the certain condition. ${ }^{5}$

Public opinion can serve as an important tool for leaders to achieve a policy success. Eshbaugh-Soha and Linebarger, for example, note that the president does need public support and he can shape the public opinion. He goes on to say that, the way the president frames the issue of war in his presidential address or the tone of the presidential rhetoric increases the citizens ${ }^{\text {ee }}$ support for the way the president handles the war, and this is shown in the case of Iraq war. ${ }^{6}$

Second, the study of public opinion is important because scholars of public opinion seem to have reached a consensus that the public can develop and hold coherent views on foreign policy. Although the citizens do not always closely pay attention to the details of international politics and have significant

Nexus. Mershon International Studies Review 42 (1998): 33.

4 Ibid.,33.

5 Ibid.,29.

6 Matthew Eshbaugh-Soha, and Christopher Linebarger."Presidential and Media Leadership of Public Opinion on Iraq." Foreign Policy Analysis 10 No. 4 (2014): 351-369. informational disadvantage vis-à-vis leaders or the key foreign policy makers, they compensate by employing other cues that allow them to make judgments with the limited information that is available to them. ${ }^{7}$

Third, there is little research on the way citizens form their opinion on foreign affairs. So far, scholars such as Daniel Novotny, David Siroky, Alan J. Simmons, and Giorgi Gvalia are interested in examining the elites ${ }^{\text {ee }}$ perception and their determinants. ${ }^{8}$

There is, however, an emerging acknowledgment among scholars who study the role of domestic politics in shaping the state's foreign policy, which examines the individual level perception matters. A study by Siroky, Simmons, and Gvalia represents the most recent effort to understand public opinion on Georgians"e most important political and economic partner. In their $2017^{\text {ee }}$ s piece, they attempt to assess the mechanisms by which the public develop foreign policy preferences.

In their attempt to unpack the causes of the variations in the public " perception on the most appropriate bilateral partner for their country, they choose Georgia as a case study. They describe Georgia as one of post-Soviet battleground countries in the Eastern Europe, where the United States and Russia compete for influence. ${ }^{9}$ The strategic value of Georgia for these two most powerful states in the world makes their study of the mass opinion's preferences toward major power an interesting and a valuable one, because it allows us to better think about the contemporary foreign policy challenges facing both domestic and foreign decision makers who try to forge a bilateral or trilateral relationship.

\footnotetext{
7 Baum and Potter, 43-44.

8 Daniel Novotny. Torn Between America and China: Elites Perception and Indonesian Foreign Policy. Singapore:Institute of Southeast Asian Studies.2010.; Siroky, David S., Alan James Simmons and Giorgi Gvalia . "Vodka or Bourbon? Foreign Policy Preferences Toward Russia and the United States in Georgia". Foreign Policy Analysis (2017): 2.

9 Siroky, et.al, 3 .
} 
This paper, which focuses on the correlational study, seeks to advance the literature on the mass opinion by reexamining

Siroky"s, Simmons"s, and Gevalia's arguments and studying the extent to which political value plays a role in shaping public opinion. They argue that religious factor, economic satisfaction, and individual perception on the role of government determine the mass attitude towards Russia and America. Their theory represents not only the latest explanation of one of the most important, yet understudied topic in Foreign Policy Analysis but also the most comprehensive argument about the public preferences and their determinants.

$$
\text { I seek to replicate and expand }
$$

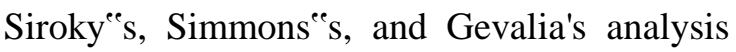
by offering an alternative explanation they did not test for, which is a political value. As the research on determinants of individual preferences of Europeans supports toward the European Union, and the Central and Easter

Europeans $^{\text {ee }}$ choice of external partner demonstrate, political value constitutes one of the key determinants of individual foreign policy preference.

I argue that the more people respect democracy, the lower their probability of siding with Russia in both political and economic terms, and the higher their probability of choosing the United States as the most preferred bilateral partner of their country, Georgia. This argument is then tested along with Siroky"es, Simmons"es, and Gevalia's explanation. On the whole, the results from the statistical study suggest that their explanation has stronger explanatory power compared to my argument in explaining people ${ }^{\text {ees }}$ decision to choose Russia or the United States as their countryes external partner. Although a single case does not provide a strong basis to reject the theory that political value shapes individual foreign policy preference of political value, it should make the student of political science pause and call into question this idea.

The remainder of this paper is divided into six sections. Following the introduction, the second section summarizes Siroky"s, Simmons"s, and Gevalia's theory, and introduces an alternative explanation of the individual preferences towards the major powers. The third section describes the research design and data that are used to test the hypothesis. The fourth section provides a logistic model to test the contending theories on individual preferences. The fifth section explains the results. The sixth section concludes and highlights the possible research avenues for future research on the relationship between public opinion and foreign policy.

\section{What determines the variations at the individual-level preferences toward major power? Contending theories and hypothesis to test}

The literature about the determinants of the individual-level preferences at the battleground or post-Soviet countries, whether they are proRussia, pro-West such as the European Union, or pro-United States, within the Foreign Policy Analysis provides conflicting explanations on what generate such preferences. Siroky, Simmons, and Gvalia focus on three domestic factors that determine the individual ${ }^{\text {ee }} \mathrm{s}$ affinity towards either Russia or the US, which are religion, economic satisfaction, and the role of government.

They point out that shared religious faith between two countries can influence the way people think about the proper direction for their country regarding external relations. They note that most observers argue that there is a religious similarity between Georgia and Russia. These two countries have a strong Orthodox Church influence. In Georgia, the Orthodox Church is an influential establishment in the society. They are often critical of the government policies, including the government ${ }^{\text {es }}$ pro-Western policies, and try to mold public opinion. ${ }^{10}$ Given these facts, they propose the following hypothesis:

\footnotetext{
${ }^{10}$ Siroky, Simmons, and Gvaliae"s, 7 .
} 
H1: More religious individuals will be more likely to favor closer ties with Russia

Their other hypothesis focuses on the individuales view of the role of the government. The existing studies of post-

Socialist ${ }^{\text {es }}$ s societies ${ }^{\text {ee }}$ attitudes towards the

European Union point out that the society of the former Soviet countries tends to see the government as parent. These people often reminisce of the good-old-days under the Soviet, where the government will do anything to "raise" them. Such nostalgia is apparently common among post-Soviet countries, where the older people would remember that they had everything in the past. ${ }^{11}$ These findings lead them to propose a second hypothesis, which is: $\mathrm{H} 2$ : Individuals with a paternalistic view of government will be more likely to think that their country should forge closer political and economic ties with Russia

The last factor that they think affects the people ${ }^{\text {ee }}$ affinity towards one of major power is the individuale ${ }^{\text {ee }}$ perception of their economic status. In the context of the study on European integration, some scholars find out that people evaluate the benefit of a partnership with a country based on the cost and benefit of such external relation. Studies on post-Soviet countries find out that winners from the integration appear more likely to support the European Union membership. Such attitude is also apparent in the context of the post-Soviet countriese relation with the Western country, such as the United States. ${ }^{12}$ Thus, these findings lead them to advance the third hypothesis:

$\mathrm{H} 3$ : Economic "losers" are more likely to favor closer ties with Russia

In addition to the three determinants above, there are other possible explanations as to why individuals in post-Soviet countries develop a pro-Russian, or pro-Western attitude. The other possible explanations include the cultural and social economic background, and

\footnotetext{
${ }^{11}$ Siroky, Simmons, and Gvaliae ${ }^{\text {ee }}, 7$.

12 Siroky, Simmons, and Gvalia"es,8.
}

the role of informal social environments such as friends, acquaintances, colleagues, and neighbors as guidance in evaluating foreign policy issues. ${ }^{13}$

The other factor that also plays a role in shaping the individual preferences of their county's external partner is political value. The literature on the study of Central and Eastern Europe points out that democratic and freemarket values, as well as positive attitudes towards minorities and liberal principles, lead to a high level of support for the European Integration. ${ }^{14}$ These countries view that the European Union is not only a valuable avenue to achieve economic gains, but also instrumental to improve the democracy and freedom in their country.

$$
\text { The European Union (EU) is }
$$
committed to supporting human rights, including the rights of persons belonging to minorities, democracy, equality, human dignity, and the rule of law. ${ }^{15}$ The EU is also built upon the principle of good governance,

\footnotetext{
13 Andrej Nowak, Jacek Szamrej and Bibb Latane. "From Private Attitudes to Public Opinion: A Dynamic Theory of Social Impact." Psychological Review 97 No. 3(1990): 362-76.

Rachel Cichowski. "Western Dreams, Eastern Realities: Support for the European Union in Central and Eastern Europe." Comparative Political Studies 33 No. 10(2000): 1243-78; Piret Ehin.

"Determinants of Public Support for EU Membership: Data from the Baltic Countries,"

European Journal of Political Research 40 No.1 (2001): 31-56; Joshua Tucker, Alexander Pacek and Adam Berinsky. "Transitional Winners and Losers: Attitudes towards EU Membership in Post-

Communist Countries." American Journal of Political Science 46 No. 3(2002): 557-71; Kazimierz M. Slomczynski, and Goldie Shabad "Dynamics of Support for European Integration in Post-Communist Poland." European Journal of Political Research 42 No. 4 (2003): 503-39; Tanasoiu Cosmina, and Constantin Colonescu. "Determinants of Support for European Integration." European Union Politics: SAGE Publications 9 No. 3(2008): 363-377.

${ }^{15}$ European Commission. "EU Charter of Fundamental Rights." Accessed April 30, 2017.http://ec.europa.eu/justice/fundamentalrights/charter/index_en.htm.
} 
transparency, and the irreversibility of reforms. ${ }^{16}$

The Eastern and Central European countries which underwent transition period and have little information about the EU based their decision to join the EU by looking at the political values attached to the idea of Europe. In their view, the Western Europe is more superior regarding political values. The EU is perceived to have a truly cosmopolitan outlook, where it embraces a variety of cultures, types of people, and ways of life, prosperous and democratic life. In contrast, the Eastern and Central European countries see their countries as underdeveloped, authoritarian, and provincial. Thus, the admiration for democratic value among people and the desire to live a better political life in these countries led them to support their countries membership in the EU. ${ }^{17}$

The European Union is not the only entity which embraces democratic value. Some Scholars who study democracy and political culture in some of the Eastern European countries such as Klingemann, Fuchs, Zielonka note that countries from this part of the world associate democratic value with the United States. Although the people from this region think that democracy has its problem, many people think that it is better than any other form of government, such as the political system where the government is led by the army, or a strong leader who does not bother with parliament and elections. ${ }^{18}$ This conjecture leads me to a hypothesis that:

H4: Those who value democracy, will be more supportive of political relations with the United States

\footnotetext{
$\overline{16}$ Slomczynski, and Shabad,503-39; Tanasoiu and Colonescu,367.

17 Stephen White, Ian McAllister and Margot Light."Enlargement and the New Outsiders." Journal of Common Market Studies 40 No.1(2002): 135-53 ; Tanasoiu and Colonescu,367.

${ }^{18}$ Hans-Dieter Klingemann, Dieter Fuchs, and Jan Zielonka,eds. (USA:Routledge. 2006). 18,41.
}

Since the political value, which is democratic value, is a political measurement, I expect that it correlates with only the political ties and not the economic ties.

As the literature of public opinion in the context of EU, and Central and Eastern Europe show, the origin of democracy in the certain country is irrelevant in determining publices support for the choice of their country ${ }^{\text {ee }}$ foreign partners. Therefore, in the case of Georgia, it is irrelevant how Georgia ends up adopting certain type political system or value, for example, whether in the past, foreign involvement influences the democratization.

Another point worth emphasizing is the plurality of political values among the society. Some people believe and support democratic or authoritarian values more than others. Even though the political system of their country is not a democracy, people can have an aspiration to live under democracy one day or vice versa. Hence, the supporter of democracy will prefer their country to make friendship with a democratic country as opposed to authoritarian country.

\section{Method, variables, and data ${ }^{19}$}

The data largely builds on the replication materials, including the codebook, and coding, that is provided by the authors, Siroky, Simmons, and Gvalia, which I obtained through personal correspondence with one of the author. These materials are also available online on the Harvard Dataverse website. The reason these three authors used the dataset on Knowledge and Attitude towards the European Union in Georgia in 2011 is that this dataset was the most recent dataset on Georgia when they wrote the paper.

I use their dataset for the following dependent variables: political ties with Russia (POLRUS), economic ties with Russia (ECONRUS), political ties with America

\footnotetext{
19 The $\mathrm{R}$ code for this paper is available upon request.
} 
(POLUS), and Economic Ties with America (ECONUS).

Siroky, Simmons, and Gvalia ask two questions as the dependent variable. There are in total four tables, as you will see later in this paper. For the first two tables, the public response is measured using the survey question: "In your opinion, should Georgia have the closest political cooperation with Russia?". The responders are given two choices of an answer: "yes," and "no." In the second set of models, the dependent variable deals with economic cooperation with Russia. The question that the three authors ask is "Should Georgia have the closest economic cooperation with Russia?". There are two possible answers that the responders can choose: "yes," or "no." They three authors also pose a question about the public opinion toward the United States. The question and answer are the same as above, except that they replace America with Russia. ${ }^{20}$

I also use their dataset for the three independent variables: Religiosity (RELSERV2), paternalism (GOVTROL2), and satisfaction with Income (CURRUNG2). In addition to that, I use and modify one variable that is related to the political value (ICITVOTE, ICITVOTE. ord).

To measure religious belief, the surveyors ask how often the interviewees go to the church. The interviewers assign a score ranging from 1 to 5 . One means frequent church attendance. Frequent attendance at church service reflects adherence to Orthodox Church teachings, something that Georgia and Russia shares in common, and exposes them to political values of the religious leaders in this Church. $^{21}$

In determining the level of paternalism, which refers to the idea that a government should play a role of parents for the citizens, the surveyors ask whether the interviewees agree or agree very strongly with the statement that people are like children, and

\footnotetext{
${ }^{20}$ Siroky, et.al, 8 .

${ }^{21}$ Siroky, et.al, 6-7.
}

the government should take care of them like a parent. The surveyors assign score 1 to 2 , with one means strongly agree with the statement. Paternalism is very strong in a country like Russia, and some people in Georgia often reminisce about the good old day of the paternalistic system. $^{22}$

The third independent variable is measured by identifying people ${ }^{e e}$ economic condition under the current system. The surveyors ask the respondents to write the rung of the economic ladder they think their household stands on at present, with the first rung of this ladder to the lowest possible economic position in the society. Those who feel like they are the loser under the current economic system, which adopts a Western economic system, tend to yearn a closer relationship with Russia. ${ }^{23}$

With regards to the measurement of the alternative independent variable, the political or the democratic value, I employ the Schumpeterian definition of democracy that centers on competitive elections. ${ }^{24}$ In the dataset, the variable of political value, which is the democratic value, is based on one main question "To be a good citizen, how important would you say it is for a person to vote in elections", The interviewers assign score 1 to 4 to the answer from respondents from -2 to 1 , with four means very important. ${ }^{25}$

Siroky, Simmons, and Gvalia also include other variables as controls such as

Respondent"s age (RESPAGE), respondent"s education (EDUDGR2), travel to Russia (TRAVELRU2), travel to America (TRAVELUS2), belonging to the Orthodox Christian Faith (Ortho), urban residence

\footnotetext{
${ }^{22}$ Siroky, et.al, 7 .

${ }^{23}$ Siroky, et.al, 7

${ }^{24}$ Steven Levitsky, and Lucan Way. Competitive Authoritarianism: Hybrid Regimes after the Cold War. (Cambridge University Press. 2010),6.

Caucasus Research Resource Centers, Georgia .2011. "Knowledge and attitudes toward the EU in Georgia, 2011.AccessedApril 30, 2011. http://caucasusbarometer.org/en/eu2011ge/downloa ds/.7.
} 
(URBAN), ethnic Georgian (EG2), trust president of Georgia (TRUPRES2), knowledge of the Russian language (RusOnly2), and knowledge of the English language (EngOnly). These variables are held constant to assess the relationship between the main four independent variables and the independent variable. $^{26}$

The description of the independent, dependent, and control variables are available in their codebook which is also available online on the Harvard dataverse website. ${ }^{27}$ I use the $\mathrm{R}$ statistical programming language to analyze the relationship between the dependent variables, control variables, and independent variable.

The descriptive statistics of the three original and one alternative independent variables are provided in Table 1.

Table 1. Descriptive Statistics of the Independent Variable

Table 1: Descriptive Statistic

\begin{tabular}{lccccc}
\hline \hline Statistic & $\mathrm{N}$ & Mean & St. Dev. & Min & Max \\
\hline RELSERV2 & 1,818 & 1.930 & 1.327 & 0 & 4 \\
GOVTROL2 & 1,708 & 2.332 & 1.069 & 1 & 4 \\
CURRUNG2 & 1,800 & 1.728 & 0.732 & 1 & 4 \\
ICITVOTE.ord & 1,308 & 3.832 & 0.595 & 1 & 4 \\
\hline
\end{tabular}

To analyze the data, I use logistic regression model. This model is used because the outcome or independent variable is dichotomous or binary. ${ }^{28}$ As mentioned in the previous page, the responders of the survey only have two possible choices of answer when asked about their opinion towards both the US and Russia.

\footnotetext{
${ }^{26}$ Siroky, et.al, 7.

27 David S. Siroky, Alan James Simmons and Giorgi Gvalia. "Replication Data for Vodka or Bourbon? Foreign Policy Preferences Toward Russia and the United States in Georgia”. Accessed April 30, 2017. https://dataverse.harvard.edu/dataset.xhtml?persiste ntId=doi:10.7910/DVN/A3HBWB.

${ }^{28}$ James E Monogan III. Political Analysis Using $R$. (USA: Springer.2015), 100.
}

\section{Results}

Four sets of nine models are estimated to test four hypotheses. The results for all models in Table 1 and 2 showed that proRussian attitude in both political and economic domains is driven by the three independent variables that Siroky, Simmons, and Gvalia propose. The significance of the relationship between the independent and dependent variable is summarized with the asterisks or stars attached to the independent variable. The higher the stars, the more statistically significant the relationship between the independent and dependent variable is.

The model 8 in table 1 shows that the p-value of religiosity is significant, and the role of government and economic satisfaction are very significant. These three variables are still correlated with the pro-Russia attitude in the political domain when the model 9 in table 1 includes the democratic value variable. The logistic model 9 in table 1 also shows that democratic value is not statistically significant (p-value is above 0.1). In other words, the democratic value cannot predict the probability, of the people of Georgia choosing Russia as the most preferred political partner for their country.

Table 1 also reports the AIC or Akaike Information Criterion, which is a good fit index. The model 9 in table 1 reports a lower AIC value compared to the other models in table 1. The lower AIC stems from the inclusion of the four independent variables, and the control variables. The AIC is used to determine if the sample data are consistent with the hypothesized relationships between the independent variables and the dependent variable. The low value indicates that the model has a good fit. 
Table 2. Determinants of Individual Support for Political Ties to Russia

\begin{tabular}{|c|c|c|c|c|c|c|c|c|c|}
\hline & \multicolumn{9}{|c|}{ Dryindent aniathi } \\
\hline & & & & & Polntes & & & & \\
\hline & (a) & (2) & (a) & (4) & (5) & (6) & (7) & (8) & (18) \\
\hline ЙEAPACE: & $\frac{0.012 \cdots}{(0000)}$ & $\begin{array}{l}8.0010^{* * *} \\
(0.00)\end{array}$ & 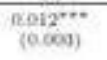 & 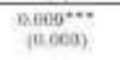 & $\begin{array}{l}0.011 \cdots \\
0.0009\end{array}$ & 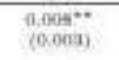 & $\begin{array}{c}0.910^{+* * *} \\
(0.009)\end{array}$ & $\begin{array}{l}0.000 \cdots \\
\text { (0.009) }\end{array}$ & $\begin{array}{l}60023^{* * 1} \\
(0004)\end{array}$ \\
\hline EDUDCR2 & (a) & $\begin{array}{l}0009 \\
00049) \\
(0.049)\end{array}$ & 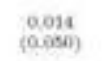 & $\begin{array}{l}0.023 \\
0.02010\end{array}$ & (B.017) & $\begin{array}{l}8028 \\
\text { sentas }\end{array}$ & $\begin{array}{l}0.017 \\
0.0509)\end{array}$ & 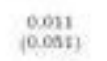 & $\begin{array}{l}6001 \\
(0 \times 0 \text { in })\end{array}$ \\
\hline Amonly? & $\frac{-0.130}{(0.105)}$ & $\begin{array}{l}-0.126 \\
(0.106)\end{array}$ & $\begin{array}{l}-0.111 \\
(0.108)\end{array}$ & (0.106) & $\begin{array}{l}-0.130 \\
\text { (10. IIiv) }\end{array}$ & $\begin{array}{l}-0,136 \\
(0.106)\end{array}$ & $\begin{array}{l}-0.14 \% \\
0.1063\end{array}$ & - 0.118 & $\begin{array}{l}-0,157 \\
(0,150)\end{array}$ \\
\hline TRAVHLnua & $\frac{-0.276^{*}}{(0.136)}$ & $\begin{array}{l}-02040^{\circ} \\
(0197)\end{array}$ & $\begin{array}{l}-11: 24 a^{*} \\
\{0(141)\end{array}$ & $\frac{-0.262^{*}}{(0.136)}$ & 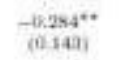 & $\frac{-0.244^{*}}{(0.199)}$ & $\begin{array}{l}-6.224 \\
(10.241)\end{array}$ & $\begin{array}{l}-11.260^{*} \\
(0-349)\end{array}$ & $\begin{array}{l}-0.274 \\
(0.189)\end{array}$ \\
\hline Ontio & (0.211 & (0.25) & $\frac{-0.174}{(0.178)}$ & (0.175) & 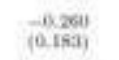 & (11392 & $\begin{array}{l}-6.1758 \\
(0.1793)\end{array}$ & 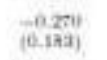 & $\begin{array}{l}\text { cazos } \\
(02211)\end{array}$ \\
\hline thas & $\frac{-a z 2 \pi}{(0.19)}$ & $\begin{array}{l}-10026^{* *} \\
(10.197)\end{array}$ & $\frac{-1,25 x^{*}}{10.167}$ & 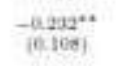 & $\begin{array}{l}-0.258 * * \\
(0.1121\end{array}$ & 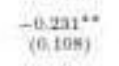 & $\begin{array}{l}-10.212 . * \\
(0.10)\end{array}$ & $\begin{array}{l}-0.238 * * \\
(10.112)\end{array}$ & $\frac{-0.217}{(0.1 \times n)}$ \\
\hline EC2 & $\begin{array}{l}0.227 \\
(0.212)\end{array}$ & $\begin{array}{l}\text { Bs4t5 } \\
(02214)\end{array}$ & $\begin{array}{l}6.346 \\
(0.215)\end{array}$ & $\begin{array}{l}\text { e. } 393 \\
\text { (is236) }\end{array}$ & $\begin{array}{l}0.31^{\circ} \\
(0322) \\
(0.22)\end{array}$ & $\begin{array}{l}\text { e.353 } \\
(0.217)\end{array}$ & $\begin{array}{l}\text { (8) } 367^{\circ} \\
(0.21 i)\end{array}$ & $\begin{array}{l}0.4000 \\
(0.22)\end{array}$ & $\begin{array}{l}0.900^{\circ} \\
(0.20+1)\end{array}$ \\
\hline Thipless & $\begin{array}{l}0.012 \\
\text { (10049) }\end{array}$ & $\begin{array}{l}\text { bog1 } \\
(0000)\end{array}$ & $\begin{array}{l}-60.017 \\
(0.042)\end{array}$ & $\frac{-6033}{(0.041)}$ & $\begin{array}{l}-6014 \\
00042)\end{array}$ & $\begin{array}{l}-6,012 \\
\text { (1)-041) }\end{array}$ & $\begin{array}{l}-10049 \\
(8.042)\end{array}$ & $\frac{-004}{(00042 i}$ & $\begin{array}{l}\text { sonet } \\
\text { soossy) }\end{array}$ \\
\hline MRISERiv2 & & $\begin{array}{l}\text { b.oogr. } \\
(0.041)\end{array}$ & & & & $\begin{array}{l}0.090 *: \\
0 \mathrm{~B}-041)\end{array}$ & (0.091. & $\begin{array}{l}0.116 \cdots \\
(0.042)\end{array}$ & $\begin{array}{l}\text { o.cess: } \\
\text { (0.0.0si) }\end{array}$ \\
\hline GOVTROL: & & & 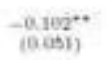 & & 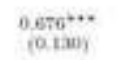 & & $\frac{-0.00 e^{*}}{(0.001)}$ & o.t05 & 0.728*t. \\
\hline CUnuUNaz & & & & $\underset{(0.07)}{-0.02 y)}$ & $\begin{array}{r}-1.240 \cdots \\
\text { (0.193) }\end{array}$ & 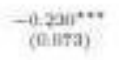 & & 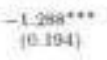 & $\begin{array}{l}-\mathrm{t} .317 \cdots \\
(0252)\end{array}$ \\
\hline ICrTvort ari & & & & & & & & & - o.oun \\
\hline Coventsia & $\begin{array}{l}-0.0711 \\
(0.322)\end{array}$ & $\begin{array}{l}-6041^{\circ} \\
\text { (203ta) }\end{array}$ & 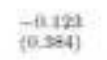 & $\cos _{(0,3 x+1)}$ & $\begin{array}{l}\text { 6.341 } \\
\text { (0.399) }\end{array}$ & $\begin{array}{l}-0.009 \\
(0,989)\end{array}$ & - & $\begin{array}{l}0.167 \\
\text { (0.46) }\end{array}$ & $\begin{array}{l}0234 \\
(03326)\end{array}$ \\
\hline 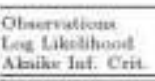 & 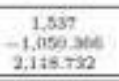 & 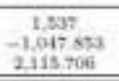 & $\begin{array}{r}1.470 \\
-900.013 \\
2005.1124 \\
\end{array}$ & 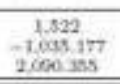 & $\begin{array}{r}1.460 \\
\quad 571764 \\
1,560.565 \\
\end{array}$ & 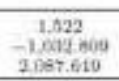 & $\begin{array}{c}1.470 \\
-500.650 \\
2015.2 \pm 0\end{array}$ & $\begin{array}{r}1,460 \\
-200021 \\
1.900 .042\end{array}$ & 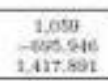 \\
\hline Nele & & & & & & & & $0.1 .{ }_{0}{ }_{p<0}$ & $\cdots_{p<001}$ \\
\hline
\end{tabular}

In table 2, the logistic model establishes the relationship between the four independent variables and the pro-Russian attitude in the 2 also shows that democratic value cannot predict the probability of the people of Georgia choosing Russia as the most preferred economic partner for their country.

Table 2 also reports the AIC or Akaike Information Criterion, which is a good economic realm. The model 9 in the table 2 includes all four independent variables and control variables. The logistic model 9 in table fit index. The model 9 in table 2 reports a lower AIC value compared to the other models in table 2. The low value indicates that the model has a good fit. 
Table 3. Determinants of Indvidual Support for Economic Ties to Russia

\begin{tabular}{|c|c|c|c|c|c|c|c|c|c|}
\hline & \multicolumn{9}{|c|}{ Dremiknt =aruitit } \\
\hline & & & & & ECONMUE & & & & \\
\hline & (i) & (2) & (3) & (4) & (3) & (6) & (7) & (8) & (a) \\
\hline МЕ:РАСE & $\begin{array}{l}0.010 * \cdots \\
(0.002)\end{array}$ & $\begin{array}{l}0.00 \pi^{*+1} \\
(0000)\end{array}$ & 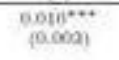 & $\begin{array}{l}000 \theta^{* * *} \\
0.00 y_{y}\end{array}$ & $\begin{array}{l}0.000^{2 * *} \\
(0.60 a)\end{array}$ & $\begin{array}{l}0.006^{\circ} \\
\text { (0.009) }\end{array}$ & $\begin{array}{l}0,007^{* *} \\
\text { (8.06a) }\end{array}$ & $\begin{array}{l}\left(16000^{4}\right. \\
(0.09)\end{array}$ & $\begin{array}{l}6000 \pi^{*} \\
00004 i\end{array}$ \\
\hline EDEDars & 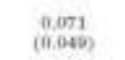 & $\begin{array}{l}0.078 \\
10.050)\end{array}$ & (2006) & 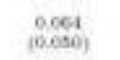 & $\begin{array}{l}8.061 \\
0.00021\end{array}$ & $\begin{array}{l}0.072 \\
\text { anatiog }\end{array}$ & $\begin{array}{l}0.074 \\
(40001)\end{array}$ & $\begin{array}{l}0,0680 \\
\text { (0.0.012) }\end{array}$ & $\begin{array}{l}0.049 \\
00.0019\end{array}$ \\
\hline Hiwonly2 & $\frac{-10.122}{(0.106)}$ & $\begin{array}{l}-2.133 \\
\text { (0.156? }\end{array}$ & $\frac{-0.15}{30.100}$ & $\frac{-613 s}{(0.00)}$ & $\frac{-6.134}{\text { (1).181 }}$ & 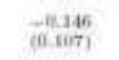 & - & $\begin{array}{l}-0.194 \\
\text { (10inis }\end{array}$ & $\frac{-0.11\rangle}{\langle 0.131\rangle}$ \\
\hline TRAVELAVI & $-0.412 \cdots$ & $\frac{-0 \operatorname{sen} x *}{(0.15)}$ & $\frac{-0.2 x+\cdots}{\langle 0.311\}}$ & 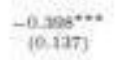 & 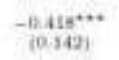 & 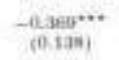 & $\frac{-0.98 a^{*}}{(0,141)}$ & $-\frac{10.346 \%}{(10.143)}$ & $-\frac{1.48 * *}{60.1673}$ \\
\hline outh & -0.06r & $\frac{-0.05 !}{0.17 m !}$ & 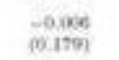 & $\begin{array}{l}\text { Oane } \\
\text { (1).177) }\end{array}$ & $\begin{array}{l}-0.05 n \\
\text { (15181) }\end{array}$ & $\frac{-\infty 0 \pi n}{(0179)}$ & $\begin{array}{l}\text { - coia } \\
\text { (1) } 1 \text { inen }\end{array}$ & -0.072 & $\begin{array}{l}\text { oots } \\
\text { (6) } 212)\end{array}$ \\
\hline DHBan: & - 71.190 & $\frac{-0.116}{10.06 \%}$ & $\frac{-0.134}{10.114}$ & -0.134 & $\frac{-0.38}{(6.312)}$ & $\begin{array}{l}-0.121 \\
(0.500)\end{array}$ & $\frac{-0.131}{(0.211)}$ & $\frac{-2131}{(0.013)}$ & $\frac{-0.293^{*}}{\langle 6.144\rangle}$ \\
\hline EG2 & $\begin{array}{l}-0.2893 \\
0.2175\end{array}$ & $\frac{-0.258}{10.2581}$ & -0.22ss & (0.226) & $\frac{-0.164}{\{0.720\}}$ & - & $\begin{array}{l}-10.096 \\
\text { (1).224) }\end{array}$ & $\begin{array}{l}-0149 \\
(0.277)\end{array}$ & $\begin{array}{l}-0.300 \\
(0.27 \pi)\end{array}$ \\
\hline TRUPBE:2 & $\sin _{(0,0)}$ & $\begin{array}{l}0.015 \\
10041)\end{array}$ & -abas & $\frac{-0.08}{(0.011)}$ & $\frac{-0.010}{(0.042)}$ & $\begin{array}{l}-6006 i \\
(0,041)\end{array}$ & $\begin{array}{l}-10018 \\
(0,042)\end{array}$ & $\begin{array}{l}-6006 \\
\text { (onati) }\end{array}$ & $\begin{array}{l}\text { coodt } \\
\text { cirisen) }\end{array}$ \\
\hline RELSESWV 2 & & (10.061) & & & & 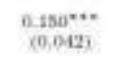 & $\begin{array}{l}0.146 \cdots \cdots \\
(0,000)\end{array}$ & $\frac{0.166 \cdots}{(0.045)}$ & 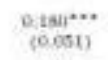 \\
\hline CONTHOLI & & & $-\frac{0.150 \% \cdots}{100521}$ & & $\frac{0.390 \% \cdots}{(0.127)}$ & & $-\frac{0.145 \cdots}{(0.052)}$ & $\frac{0.352 \cdots}{10.128\}}$ & $\frac{0.157 \cdots}{0.95 \pi}$ \\
\hline CUHRUNGE & & & & 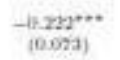 & 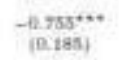 & $-18220+\cdots$ & & $-\frac{18.11 \cdots}{(0.197)}$ & 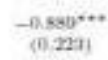 \\
\hline ictrvote nat & & & & & & & & & 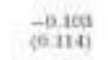 \\
\hline Contunt & $\begin{array}{l}0.090 \\
(0.3060\end{array}$ & $\frac{-0.124}{(0.325)}$ & $\begin{array}{l}0.5+6) \\
(0.300)\end{array}$ & $\begin{array}{l}0.070^{\circ} \\
(\mathrm{n} 3077)\end{array}$ & 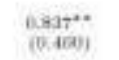 & $\begin{array}{l}0.450 \\
0.354)\end{array}$ & $\begin{array}{c}\text { a.sub } \\
(8305)\end{array}$ & (10.009 & $\begin{array}{l}\text { 10.909 } \\
\text { (0.006) }\end{array}$ \\
\hline 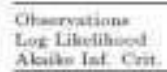 & $\begin{aligned} & 1,55 \\
&-1,030.391 \\
&-2,006.602\end{aligned}$ & 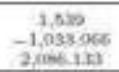 & 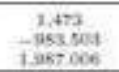 & 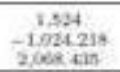 & 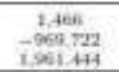 & 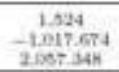 & 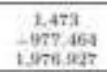 & 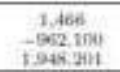 & 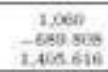 \\
\hline$\overline{\text { Nate }}$ & & & & & & & & 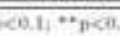 & $\cdots_{p<001}$ \\
\hline
\end{tabular}

Turning to table 3 , the result of the logistic model 9 in table 3 shows that age plays a role in people $\mathrm{s}$ decision to forge closer political ties with the United states. According to Siroky, Simmons, and Gvalia, the older people in Georgia are less likely to favor closer ties with the United States. ${ }^{29}$

This model, however, does not provide support for hypothesis four, which argues that support for democratic value will lead to increased support for the political ties with the United States.

${ }^{29}$ Siroky, et.al, 10. 
Table 4. Determinants of Individual Support for Political Ties to United States

\begin{tabular}{|c|c|c|c|c|c|c|c|c|c|c|}
\hline & \multicolumn{10}{|c|}{ Degendent warkable } \\
\hline & \multicolumn{10}{|c|}{ POLES } \\
\hline & (1) & (2) & (9) & (4) & (5) & (6) & (7) & (0) & 19) & (10) \\
\hline MFEPACE & $\begin{array}{l}-0.016^{* . .} \\
(0.004)\end{array}$ & $\begin{array}{c}-0.026 \cdots \\
(0.004)\end{array}$ & $\begin{array}{c}-0,0.0 \% \ldots \\
(11,004)\end{array}$ & $\begin{array}{l}-0.015^{2} \\
(0.004)\end{array}$ & $\begin{array}{c}-0.016 * \ldots \\
(0.004)\end{array}$ & $\begin{array}{l}-0.016^{* \ldots} \\
(0.006)\end{array}$ & $\begin{array}{l}-0.015^{2 \ldots 1} \\
(0.004)\end{array}$ & $\begin{array}{c}-6.0169+7 \\
(0.004)\end{array}$ & $\begin{array}{l}-6016 \cdots \\
(0.004)\end{array}$ & $\begin{array}{c}-0.01 x^{* \ldots .} \\
(0.004)\end{array}$ \\
\hline Frubana & $\begin{array}{l}-0.0 \mathrm{r} 1 \\
\{00 \mathrm{~s} s\}\end{array}$ & $\begin{array}{l}-0.0153 \\
(0.055)\end{array}$ & $\begin{array}{l}-0.065 \\
(0.058)\end{array}$ & $\begin{array}{l}-6.007 \\
(0.0509)\end{array}$ & $\begin{array}{l}-0.068 \\
(0.065)\end{array}$ & $\begin{array}{l}-0.060 \\
(0.059)\end{array}$ & $\frac{-0.00 \%}{(0.080)}$ & $\begin{array}{l}-0.054 \\
(0.0605)\end{array}$ & (0.065) & $\begin{array}{l}0.003 \\
(0,070)\end{array}$ \\
\hline Euronly & $\begin{array}{l}11.622 \\
(466.550)\end{array}$ & $\begin{array}{c}1384 \\
(456.517)\end{array}$ & $\begin{array}{l}13844 \\
\text { (405.095) }\end{array}$ & $\begin{array}{c}13.850 \\
(456.355)\end{array}$ & $\begin{array}{c}13.834 \\
(406.505)\end{array}$ & $\begin{array}{l}13.802 \\
\text { (456. }\end{array}$ & $\begin{array}{c}13.550 \\
(466.3355)\end{array}$ & $\begin{array}{l}\text { 1a.4sz } \\
(600.150)\end{array}$ & $\begin{array}{l}13540 \\
(506.350)\end{array}$ & $\begin{array}{c}11781 \\
\text { (511.006) }\end{array}$ \\
\hline Thavrtusa & $\begin{array}{l}1.154 \\
(0.751)\end{array}$ & $\begin{array}{l}1.146 \\
(0.76 a)\end{array}$ & $\begin{array}{l}1.161 \\
(0.751)\end{array}$ & $\begin{array}{l}1.156 \\
(0.752)\end{array}$ & $\begin{array}{l}1.101 \\
(0.751)\end{array}$ & $\begin{array}{l}1.165 \\
(0,752)\end{array}$ & $\begin{array}{l}1.155 \\
(0.752)\end{array}$ & $\begin{array}{l}1.151 \\
(0.552)\end{array}$ & $\frac{1.165}{(0.752)}$ & $\begin{array}{l}\text { e.rss } \\
\text { (0.77) }\end{array}$ \\
\hline Ortin & $\begin{array}{l}0,000 \\
(02211)\end{array}$ & $\begin{array}{l}0.020 \\
(0.211)\end{array}$ & $\begin{array}{l}\text { ceea } \\
\text { (10211) }\end{array}$ & $\begin{array}{l}a . x e a \\
(0.2 \pm 1)\end{array}$ & $\begin{array}{l}\text { II ova } \\
(0.711)\end{array}$ & $\begin{array}{l}-0.006 \\
(0.212)\end{array}$ & $\begin{array}{c}0.003 \\
(0.211)\end{array}$ & $\frac{-0.021}{(0.212)}$ & $\frac{-6005}{(02212)}$ & $\frac{-0.24 t}{(0.245)}$ \\
\hline UEBAN & $\frac{-0.103}{(0.120)}$ & $\frac{-0.192}{(0.130)}$ & -0.199 & $\frac{-0.190}{(0.190)}$ & $\frac{-6.489}{(0.1309}$ & $\begin{array}{c}-0.231^{\circ} \\
(0.132)\end{array}$ & $\begin{array}{l}-0.190 \\
\text { (0.120) }\end{array}$ & $\begin{array}{l}-0.2210 \\
\langle 0.132\rangle\end{array}$ & $\begin{array}{l}-0.250^{\circ} \\
\left(10.135^{\circ}\right)\end{array}$ & $\begin{array}{c}-0.32 \%{ }^{\circ} \\
(0.197)\end{array}$ \\
\hline BGa & -0.016 & $\frac{-0,03}{(0.25)}$ & $\begin{array}{l}0.008 \\
(0.259)\end{array}$ & $\begin{array}{l}0.009 \\
0.256)\end{array}$ & $\begin{array}{l}0.006 \\
(0.250)\end{array}$ & $\begin{array}{l}0.025 \\
(0.257)\end{array}$ & $\begin{array}{l}0.003 \\
(0.250)\end{array}$ & $\begin{array}{l}0.036 \\
(0.257)\end{array}$ & $\begin{array}{l}0.033 \\
(0.25)\end{array}$ & $\begin{array}{l}0.009) \\
(0.20) y\end{array}$ \\
\hline THomese & $\begin{array}{l}-0.006 \\
(0.059)\end{array}$ & $\begin{array}{l}-0.005 \\
(0,04)\end{array}$ & $\frac{-6004}{(0.049)}$ & $\begin{array}{l}-6004 \\
{[0.009)}\end{array}$ & $\frac{-11.004}{(0.049)}$ & $\begin{array}{c}0.014 \\
(0,060)\end{array}$ & $\frac{0.004}{(0.020)}$ & $\begin{array}{l}0.015 \\
(0,000)\end{array}$ & $\begin{array}{c}0.014 \\
(0.000)\end{array}$ & $\log _{(0.6)}$ \\
\hline HET.SEDWD & & $\begin{array}{c}-\cos x \\
(i=0.0)\end{array}$ & & $\begin{array}{l}-60090 \\
(0.0+0)\end{array}$ & & & $\begin{array}{l}-0 . \cos 20 \\
(\cos 9)\end{array}$ & 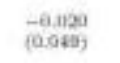 & $\begin{array}{l}-0.093 \\
(0,049)\end{array}$ & $\begin{array}{l}-0.035 \\
\text { fecoss }\end{array}$ \\
\hline covthota & & & & & & $\begin{array}{l}0.062 \\
(0.145)\end{array}$ & & $\begin{array}{l}0.005 \\
(0.051)\end{array}$ & $\begin{array}{l}0.057 \\
(1.147)\end{array}$ & $\begin{array}{l}0.259 \\
(0.273)\end{array}$ \\
\hline CERUENGZ & & & $\begin{array}{l}0.049 \\
(0.087)\end{array}$ & $\begin{array}{l}0.008 \\
(0.667)\end{array}$ & $\begin{array}{l}0.000 \\
\text { (a. } 035)\end{array}$ & $\begin{array}{r}-0.0 t 3 \\
(0.214)\end{array}$ & $\begin{array}{l}0,036 \\
\text { fo,oes) }\end{array}$ & & $\begin{array}{l}-0.0012 \\
(0214)\end{array}$ & $\begin{array}{l}-0,176 \\
\text { |15,26s; }\end{array}$ \\
\hline ICITVOTE ard & & & & & & & & & & $\frac{-0.152}{(0.142)}$ \\
\hline Crauatant & $\begin{array}{l}2,258 * \cdots \\
(0.411)\end{array}$ & $\begin{array}{c}2.401 \cdots \\
(0446)\end{array}$ & $\begin{array}{c}2.224^{* \cdots} \\
x 0.496)\end{array}$ & 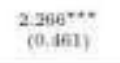 & $\frac{2.222 * \cdots}{(0.456)}$ & $2.05 x^{\cdots} \cdots$ & 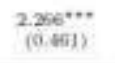 & $\underset{(0.464)}{2.119 \cdots}$ & $\frac{2 \operatorname{Eg} x+\cdots}{\langle 0,40 \pi|}$ & $\begin{array}{c}2.573 \times \cdots \\
(0.760)\end{array}$ \\
\hline $\begin{array}{l}\text { Otaryations } \\
\text { Loe Lawilboed }\end{array}$ & $\begin{array}{l}1,258 \\
\text { Twenas }\end{array}$ & $\begin{array}{l}1.535 \\
-70000\end{array}$ & $\begin{array}{l}1,824 \\
-700371\end{array}$ & $\begin{array}{c}1,724 \\
-790.192\end{array}$ & $\begin{array}{c}1,524 \\
-733.371\end{array}$ & $\begin{array}{l}1,965 \\
-760.071\end{array}$ & $\begin{array}{c}1,524 \\
-703492\end{array}$ & $\begin{array}{l}1.071 \\
-706062\end{array}$ & $\begin{array}{c}1,165 \\
-765.700\end{array}$ & $\begin{array}{l}1,000 \\
-000108\end{array}$ \\
\hline Akaskr Int Chit. & 1.511.205 & 1.612 .617 & 1.006 .242 & $1,604.183$ & 1.606 .742 & 1.553 .741 & 1.6018. 183 & 1555724 & issosss & 1,136616 \\
\hline Nete & & & & & & & & & 0,$1 ; \cdots, \cdots<0$ & $\cdots p<0,01$ \\
\hline
\end{tabular}

The analysis also assesses the cause of pro-United States attitude. In table 4 model 9, age plays a role in people ${ }^{\text {ees }}$ decision to forge closer economic ties with the United states. According to Siroky, Simmons, and Gvalia , the older people in Georgia are less likely to favor closer ties with the United States. 30

${ }^{30}$ Siroky, et.al, 10. 
Table 5. Determinants of Individual Support for Economic Ties to United States

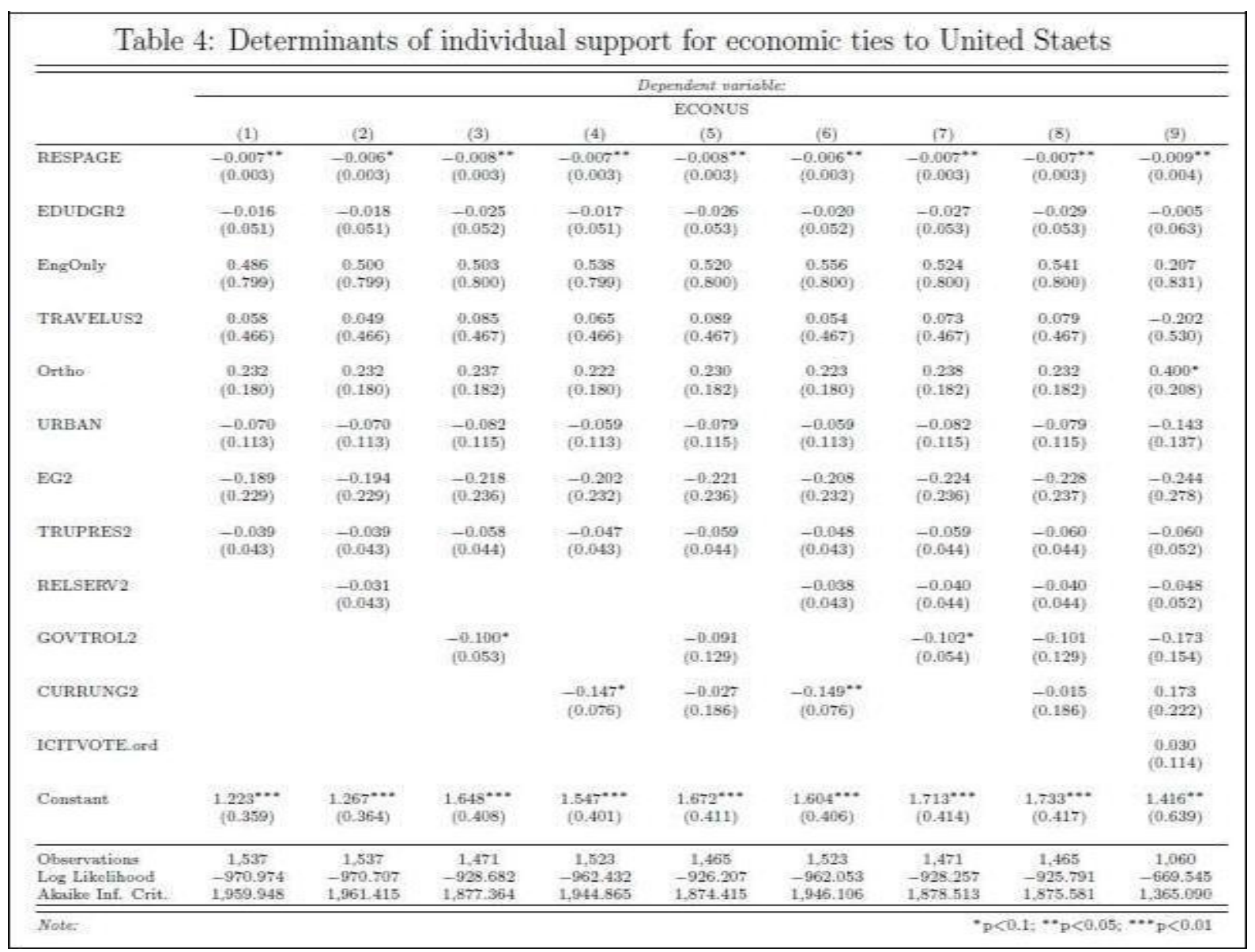

\section{Conclusion}

The preceding analysis suggests the following conclusions. First, the three independent variables that Siroky, Simmons, and Gvalia remain the best predictors of the decision of Georgian people to support Russia.

Second, given the persistence of the great game or political competition among great powers such as between China and the United States, Russia and China, and United States and Russia in other parts of the globe, such as Southeast Asia, future research could apply the same method as what Siroky, Simmons, and Gvalia employ in their research to assess the causes of the individual attitude toward great powers.

Third, future research should rely on better measurement and data of political value or democratic value to improve the present research on the relationship between this variable and individual-level foreign policy preference. 


\section{References}

\section{Books:}

Klingemann, Hans-Dieter, Dieter Fuchs, and Jan Zielonka, eds. USA:Routledge. 2006.

Levitsky, Steven and Lucan Way. Competitive Authoritarianism: Hybrid Regimes after the Cold War. Cambridge University Press. 2010. (books)

Monogan III, James E. Political Analysis Using $R$. USA: Springer.2015.

Novotny, Daniel. Torn Between America and China: Elites Perception and Indonesian Foreign Policy. Singapore: Institute of Southeast Asian Studies.2010.

Siroky, David S., Alan James Simmons and Giorgi Gvalia. "Vodka or Bourbon? Foreign Policy Preferences Toward Russia and the United States in Georgia". Foreign Policy Analysis (2017): 1-19.

\section{Journal:}

Chan, Steve, and William Safran. "Public Opinion as a Constraint against War: Democracies"e Responses to Operation Iraqi Freedom." Foreign Policy Analysis Vol.2 No. 2(2006):137-156.

Cichowski, Rachel. "Western Dreams, Eastern Realities: Support for the European Union in Central and Eastern Europe."

Comparative Political Studies 33 No. 10(2000): 1243-78.

Cosmina, Tanasoiu, and Constantin Colonescu. "Determinants of Support for European Integration." European Union Politics: SAGE Publications 9 No. 3(2008): 363 377.

Ehin, Piret. "Determinants of Public Support for EU Membership: Data from the Baltic Countries," European Journal of Political Research 40 No.1 (2001): 31-56
Eshbaugh-Soha, Matthew, and Christopher Linebarger."Presidential and Media Leadership of Public Opinion on Iraq." Foreign Policy Analysis 10 No. 4 (2014): 351-369.

Nowak, Andrej, Jacek Szamrej and Bibb Latane . "From Private Attitudes to Public Opinion: A Dynamic Theory of Social Impact." Psychological Review 97 No. 3(1990): 36276.

Powlick, Philip J., and Andrew Z. Katz. "Defining the American Public Opinion/Foreign Policy Nexus. Mershon International Studies Review 42 (1998): 29-61.

Schimmelfenning, Frank.,,The Community Trap: Liberal Norms, Rhetorical Action and the Eastern Enlargement of the European Union,' International Organisation 55 No. 1 (2001): 47-80.

Slomczynski, Kazimierz M. and Goldie Shabad."Dynamics of Support for European Integration in Post-Communist Poland." European Journal of Political Research 42 No. 4 (2003): 503-39.

Tucker, Joshua, Alexander Pacek and Adam Berinsky. "Transitional Winners and Losers: Attitudes towards EU Membership in Post-Communist Countries." American Journal of Political Science 46 No. 3(2002): 557-71.

White, Stephen, Ian McAllister and Margot Light."Enlargement and the New Outsiders." Journal of Common Market Studies 40 No.1(2002): 135-53.

Website:

Baum, Matthew A., and Phillip B.K. Potter. "The Relationship Between Mass Media, 
Public Opinion And Foreign Policy: Toward A Theoretical Synthesis." Annual Review of Political Science 11 2008:3965.

Caucasus Research Resource Centers, Georgia .2011. "Knowledge and attitudes toward the EU in Georgia, 2011.AccessedApril 30 , 2011. http://caucasusbarometer.org/en/eu2011ge /downloads/.

European Commission. "EU Charter of

Fundamental Rights." Accessed April 30, 2017. http://ec.europa.eu/justice/fundamentalrights/charter/index_en.htm.

\section{Other:}

Siroky, David S., Alan James Simmons and Giorgi Gvalia. "Replication Data for Vodka or Bourbon? Foreign Policy Preferences Toward Russia and the United States in Georgia". Accessed April

30 , 2017. https://dataverse.harvard.edu/dataset.xhtm 1?persistentId=doi:10.7910/DVN/A3H. 